\title{
Welding Tritium Exposed Stainless Steel (U)
}

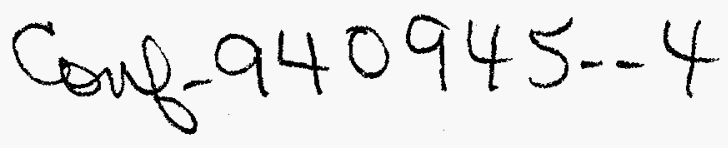

by

W. R. Kanne, Jr.

Westinghouse Savannah River Company

Savannah River Site

Aiken, South Carolina 29808

A document prepared for FIFTH INTERNATIONAL CONFERENCE ON HYDROGEN EFFECTS ON MATERIAL BEHAVIOR at Jackson Hole from 09/11/94 - 09/15/94.

\section{DOE Contract No. DE-AC09-89SR18035}

This paper was prepared in connection with work done under the above contract number with the U.S.

Department of Energy. By acceptance of this paper, the publisher and/or recipient acknowledges the U.S. Government's right to retain a nonexclusive, royalty-free license in and to any copyright covering this paper, along with the right to reproduce and to authorize others to reproduce all or part of the copyrighted paper.

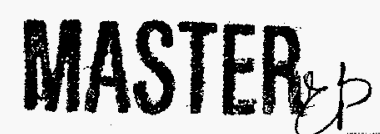




\section{DISCLAIMER}

This report was prepared as an account of work sponsored by an agency of the United States Government. Neither the United States Government nor any agency thereof, nor any of their employees, makes any warranty, express or implied, or assumes any legal liability or responsibility for the accuracy, completeness, or usefulness of any information, apparatus, product, or process disclosed, or represents that its use would not infringe privately owned rights. Reference herein to any specific commercial product, process, or service by trade name, trademark, manufacturer, or otherwise does not necessarily constitute or imply its endorsement, recommendation, or favoring by the United States Government or any agency thereof. The views and opinions of authors expressed herein do not necessarily state or reflect those of the United States Government or any agency thereof.

This report has been reproduced directly from the best available copy.

Available to DOE and DOE contractors from the Office of Scientific and Technical Information, P.O. Box 62, Oak Ridge, TN 37831; prices available from (615) 576-8401.

Available to the public from the National Technical Information Service, U.S. Department of Commerce; 5285 Port Royal Road, Springfield, VA 22161. 


\section{DISCLAIMER}

Portions of this document may be illegible in electronic image products. Images are produced from the best available original document. 
WELDING TRITIUM EXPOSED STAINLESS STEEL

\author{
W. R. Kanne, Jr. \\ Building 773-41A \\ Westinghouse Savannah River Company \\ Aiken, South Carolina 29808
}

\begin{abstract}
Stainless steels that are exposed to tritium become unweldable by conventional methods due to buildup of decay helium within the metal matrix. With longer service lives expected for tritium containment systems, methods for welding on tritium exposed material will become important for repair or modification of the systems. Solid-state resistance welding and low-penetration overlay welding have been shown to mitigate helium embrittlement cracking in tritium exposed 304 stainless steel.
\end{abstract}

\title{
Introduction
}

The detrimental effect of helium in the metal matrix was first established using stainless steel that contained helium from neutron irradiation [1]. Since that time most studies of the effect of helium on weldability have been done using material with helium in the metal matrix as a result of tritium decay [2-4]. Conventional fusion welding of stainless steel containing helium results in large surface cracks in the weld heat affected zone and in underbead cracking throughout the heataffected zone. This cracking occurs during conventional welding of tritium exposed stainless steels at helium concentrations as low as three parts per million. Alternate methods that reduce the stress and temperature during welding have been shown to significantly reduce cracking.

This report describes the use of two welding processes that have been demonstrated to eliminate surface cracking and reduce underbead cracking in the weld heataffected zone of tritium exposed 304 stainless steel. Both solid-state resistance welds and low penetration overlay welds were successfully applied to surfaces that had significant helium content from tritium charging and aging. These processes can also be used on stainless steel containing helium from neutron irradiation, such as occurs in nuclear reactors. 


\section{Welding Process Fvaluation}

\section{Conventional Welding}

Conventional gas metal arc (GMA) or gas tungsten arc (GTA) welding of tritium aged 304L stainless steel results in large toe cracks in the weld heat-affected zone. This was first determined by placing parallel bead GTA welds on 304L parts that had a large surface concentration of helium, decreasing to near zero concentration within the part. These beads are shown in Fig. $1 \mathrm{~A}$ and a dye penetrant test of the welds is shown in Fig. 1B. The surface toe cracks are clearly indicated by the dye indications. Metallographic examination of these welds showed intergranular cracking to the depth of the helium content in the metal, Fig 2A. Porosity was also evident in the welds, Fig 2B.

Additional welds were made on $0.064 \mathrm{~cm}$ thick plates charged more continuously across the thickness with helium from tritium decay. Both GTA welds (filler metal is part of the process) and GTA welds (autogenous, i.e. without filler metal) were made on these plates. Toe cracks and porosity were prevalent in these welds. A GTA weld made in a plate containing 17 appm helium is shown in Figure 3.

\section{Overlav Welding}

One solution developed for welding on tritium aged material is low-penetration gas metal arc (GMA) overlay welding. This weld results in low stress and minimum temperature in the weld heat-affected zone that is susceptible to cracking. Weld penetration averages only $0.008 \mathrm{~cm}$ into the helium-containing base metal. Test weld overlays were $2.6 \mathrm{~cm}$ wide with the bead laid in an overlapping weave pattern, Fig. 4. Application of the low-penetration overlay to tritium aged 304 stainless steel resulted in no toe cracks and only minimal underbead cracking. Compare the section of the overlay weld in Fig. 4 with the weld in Fig. 3 made in material with the same helium concentration. The low-penetration weld overlay process eliminated surface cracking and significantly reduced underbead cracking compared to conventional fusion welding processes.

Testing of the overlay weld included quantitative analysis of cracks and mechanical testing of the weld. Results of the crack analysis confirmed that underbead cracking was much less for the overlay than for conventional welds, Ref. 3-6. Mechanical testing of the overlay showed that weld strength is not compromised by the presence of helium up to concentrations of about 35 appm. Ref. 6 .

\section{Solid-State Welding}

Solid-state resistance welding has been successfully applied to tritium exposed stainless steel. Tube attachment welds were made on the surface of material that had a high surface concentration of helium. This material had experienced severe toe cracking when welded with conventional GTA welds as described above. Solidstate resistance projection welds were made on the surface as shown in Fig. 5A. Metallographic sectioning of the weld showed no cracking, Fig. 5B, even though there was some surface melting present in this weld.

Solid-state welding has been developed for joining large size parts. Using resistance upset welding, parts up to $12.7 \mathrm{~cm}$ diameter have been joined, Ref. $7 \& 8$. Parts to be joined are held in copper alloy fixtures and welded using forces up to 75,000 pounds and electrical currents up to 250,000 amperes. The resulting welds, Fig. 6, have an excellent solid-state bond with no melting. The large resistance welding process has not been demonstrated on tritium aged material. However, 
because of the demonstration described in the previous paragraph, and because of the compressive stresses produced in the weld region (as compared to the large tensile shrinkage stresses of fusion welds), it is believed that large solid-state resistance welds can be used for joining tritium aged stainless steel.

\section{The Embrittlement Process}

The mechanism of embrittlement during welding has been modeled based on experimental results. Light microscopy was used to quantify the extent of underbead and surface cracking. Tensile and bend test were used to assess the effect of base metal helium content on the mechanical integrity of the welds. Scanning electron microscopy of fracture surfaces showed a dimpled structure caused by agglomeration of helium bubbles on the grain boundaries. Transmission electron microscopy was employed to characterize the substructure in both tritiumfree and tritium exposed material. Helium bubble nucleation, growth, and agglomeration is the mechanism causing embrittlement associated with welding tritium exposed stainless steel.

\section{Conclusions}

As the lifetime of tritium exposed components increases, the need for modification or repair of these components will require joining methods compatible with the helium present in the metal from tritium decay. Conventional welding of tritium aged $304 \mathrm{~L}$ stainless steel results in severe cracking in the weld heat-affected zone. This cracking can be decreased or eliminated by techniques that reduce the stress and temperature distributions in the heat-affected zone. Two such techniques have been demonstrated on tritium aged material. A low-penetration overlay technique eliminates surface toe cracking and reduces underbead cracking compared to convention GTA or GMA welding. Solid-state resistance welding showed promise for eliminating cracking. Solid-state welding has been applied to parts considerably larger than those typically fabricated by resistance welding. These results indicate that both solid-state resistance welding and low-penetration overlay, welding are promising techniques for repair or modification of stainless steel that has been exposed to tritium.

\section{Acknowledgments}

The low-penetration GMA overlay technique was developed by E. A. Franco-Ferreira of the Savannah River Technology Center. Tritium aging was done by S. H. Goods of Sandia National Laboratories. Additional contributions to this paper were made by G. T. Chandler, K. A. Dunn, D. A. Lohmeier, M. R. Louthan, D. Z. Nelson, D. T. Rankin, and M. H. Tosten of the Savannah River Technology Center.

\section{References}

1. W. R. Kanne, Jr., Welding Journal 67-8 (1988) 33.

2. H. T. Lin, M. L. Grossbeck, and B. A. Chin, Metallurgical Transactions A 21A (1990) 2585.

3. W. R. Kanne, Jr., D. A. Lohmeier, K. A. Dunn, and M. H. Tosten, Materials Characterization, Vol. 30 (1993), pp. 23-34.

4. S. H. Goods and C. W. Karfs, Welding Journal 70-5(1991) 123.

5. E. A. Franco-Ferreira and W. R. Kanne, Jr., Welding Journal 71-2 (1992) 43.

6. W. R. Kanne, Jr., G. J. Bruck, A. Madeyski, D. A. Lohmeier, M. R. Louthan, Jr., D. T. Rankin, R. P. Shogan, G. G. Lessmann, and E. A. Franco-Ferreira, 
Proceedings of the Fifth International Symposium on Environmental Degradation of Materials in Nuclear Power Systems - Water Reactors (American Nuclear Society, 1992) p. 390.

7. Eberhard, B. J.; Kelker, J. W., Jr. 1982. High Current Resistance Welding of Nuclear Waste Containers. Welding Journal 61(6): 15 to 19.

8. Kanne, W. R., Jr. 1986. Solid-State Resistance Welding of Cylinders and Spheres. Welding Journal $65(5): 33$ to 38 . 


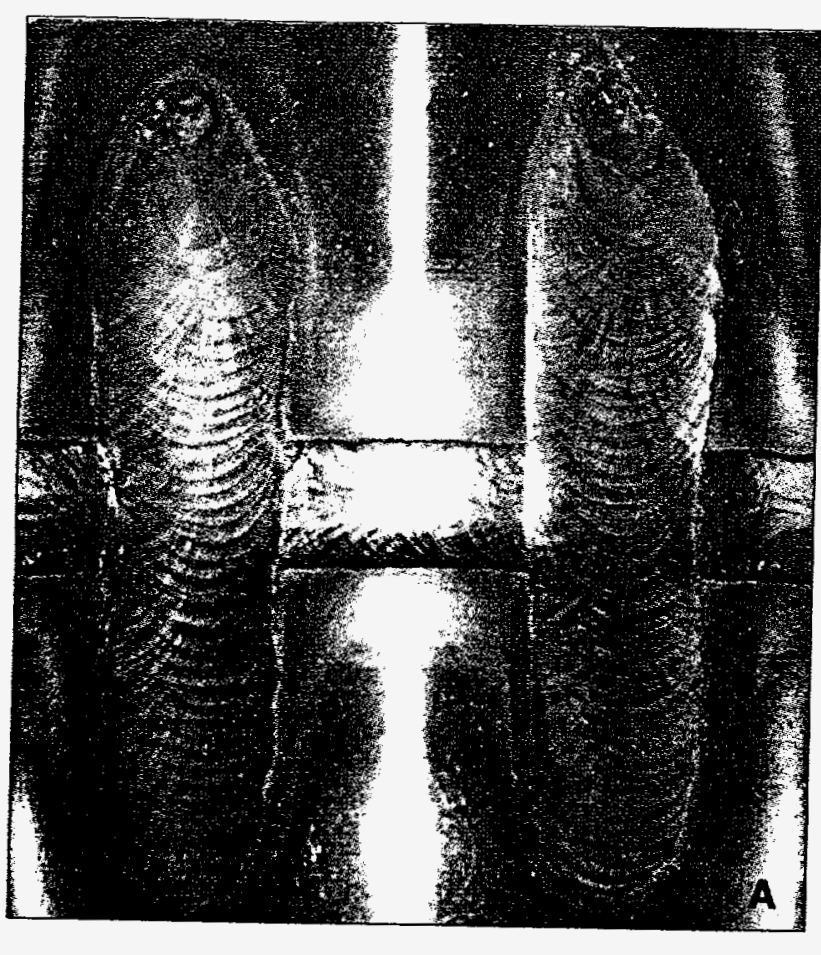

A. Parallel bead test welds

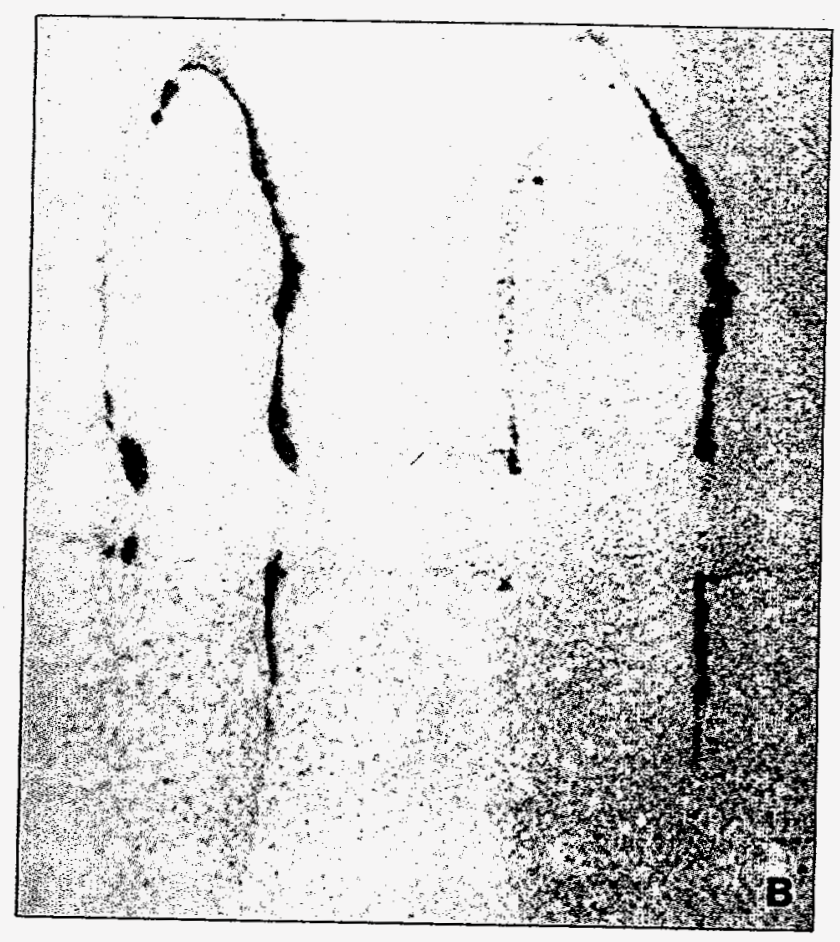

B. Dye penetrant test of welds with indications from heat-affected zone cracks

Figure 1. Welds on a tritium charged and aged surface. 


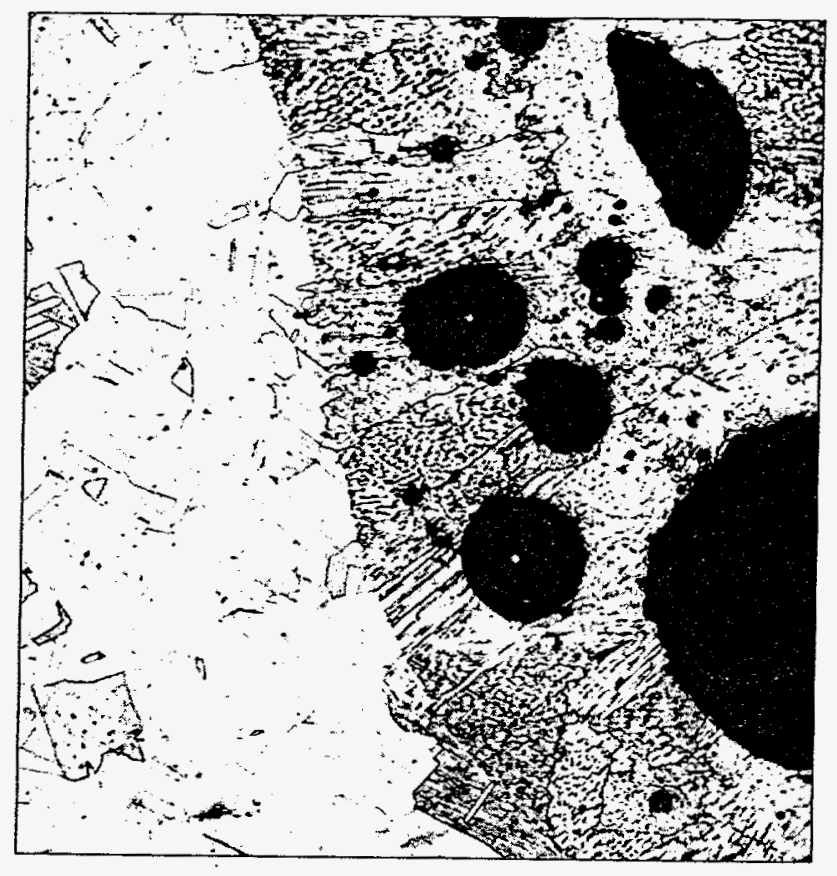

A. Porosity within weld bead

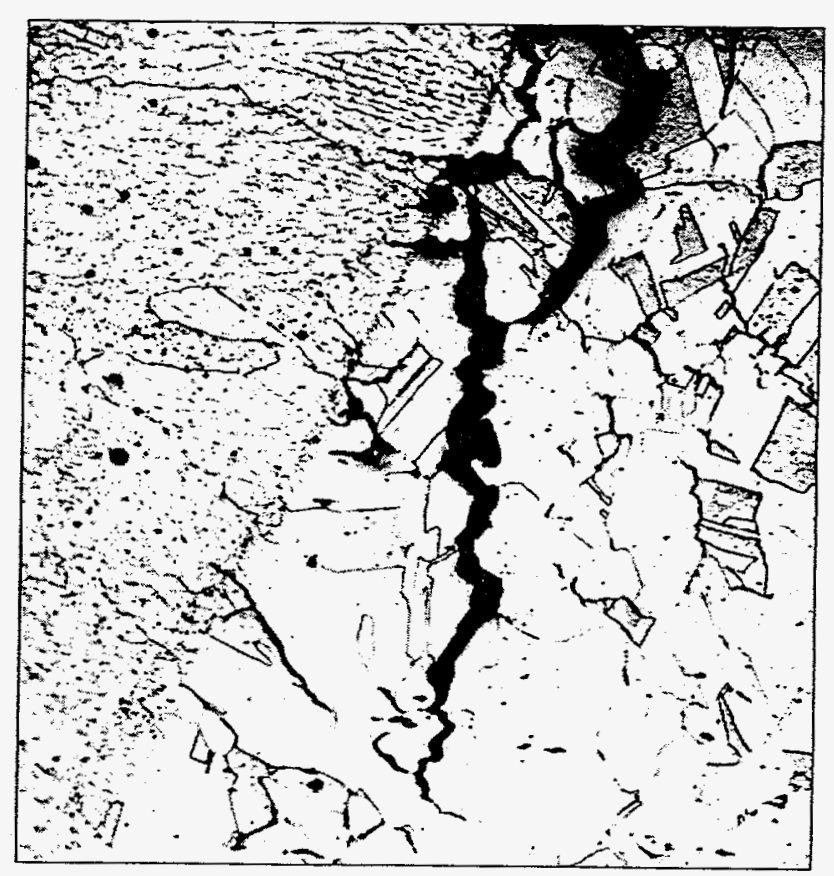

B. Intergranular cracking in weld heataffected zone

Figure 2. Metallographic sections of welds in figure 1. 


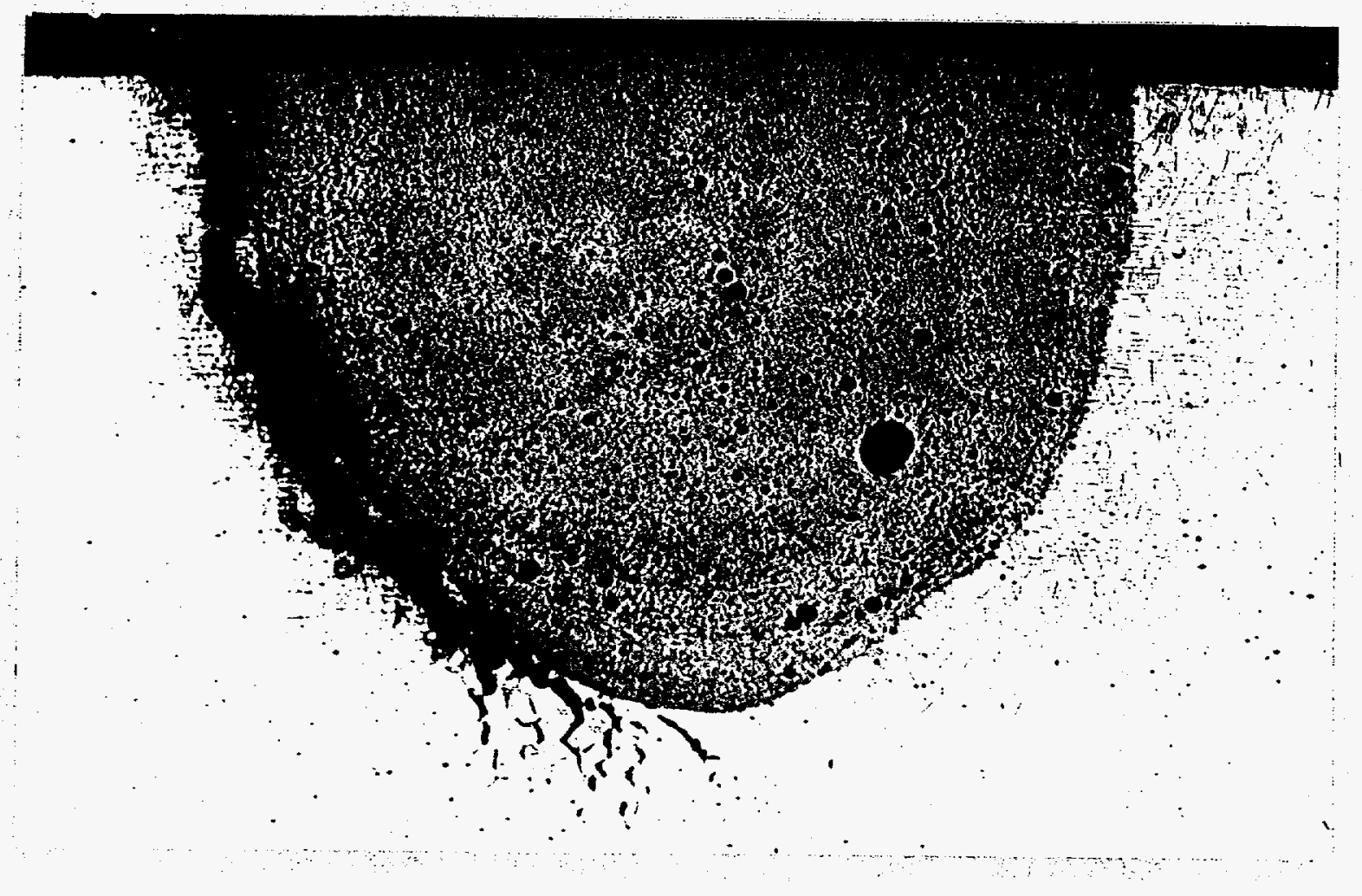

Figure 3. Conventional gas tungsten arc weld in tritium charged and aged plate containing 17 appm helium. Note extensive heat-affected zone cracking on left side of weld 


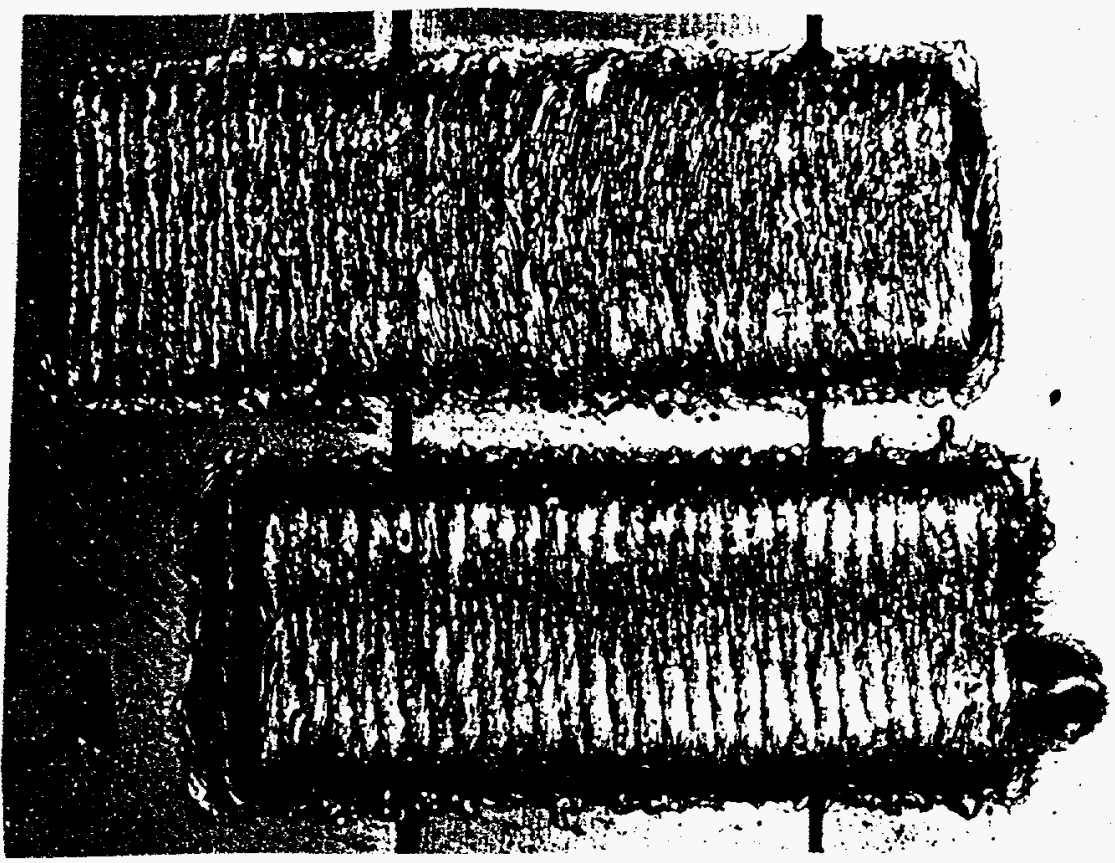

A. Surface appearance of overlay welds

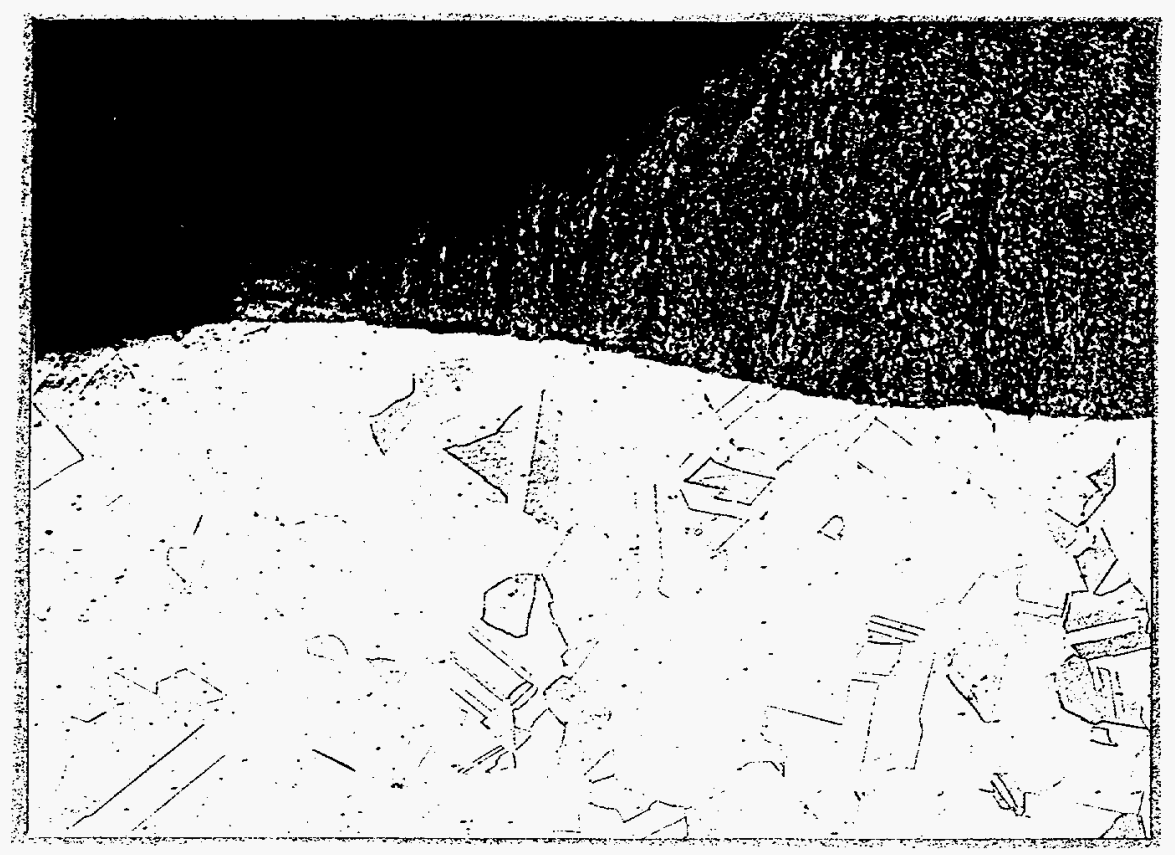

B. Metallographic section through end of overlay weld

Figure 4. Overlay weld on tritium charged and aged plate containing 17 appm helium 


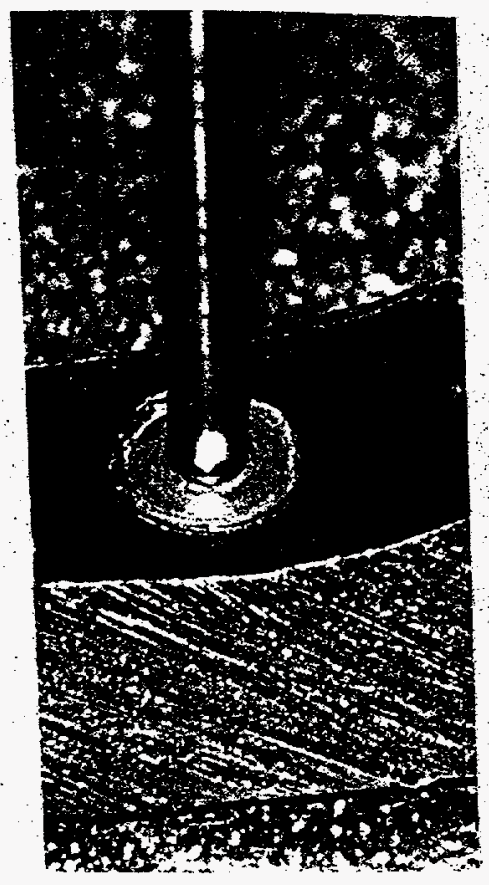

A. Tube attachment weld

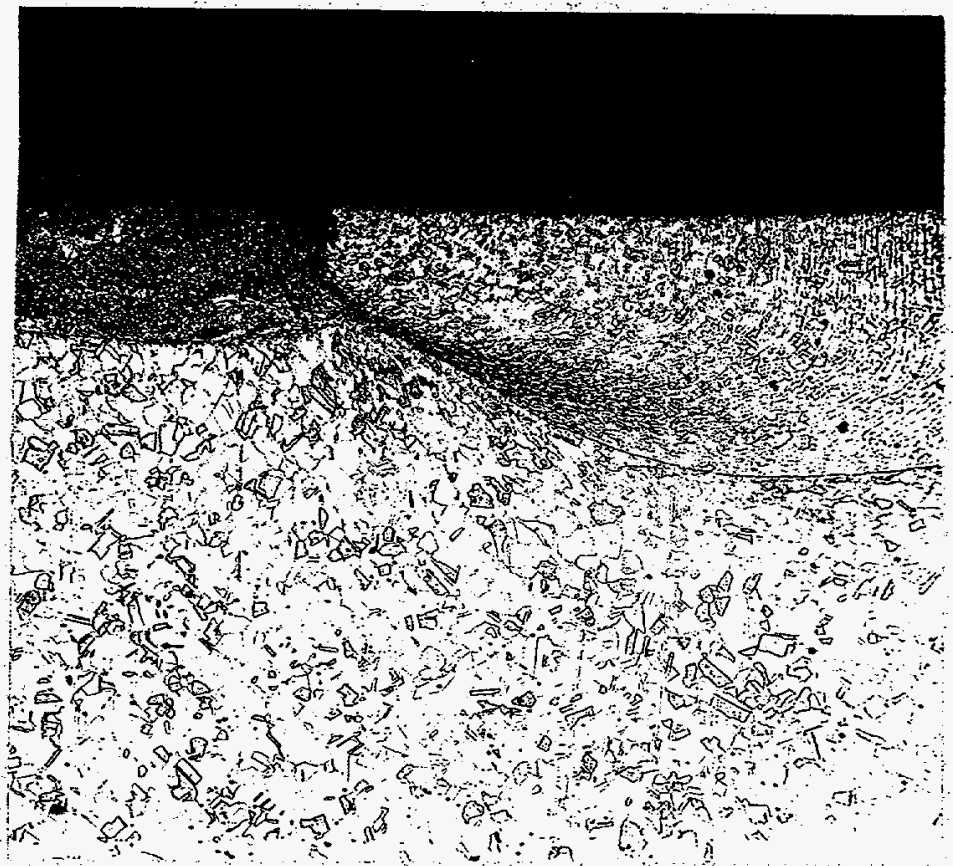

B. Metallographic section of one side of weld showing no cracks

Figure 5. Solid-state resistance weld on the surface of tritium charged and aged 304L stainless steel 


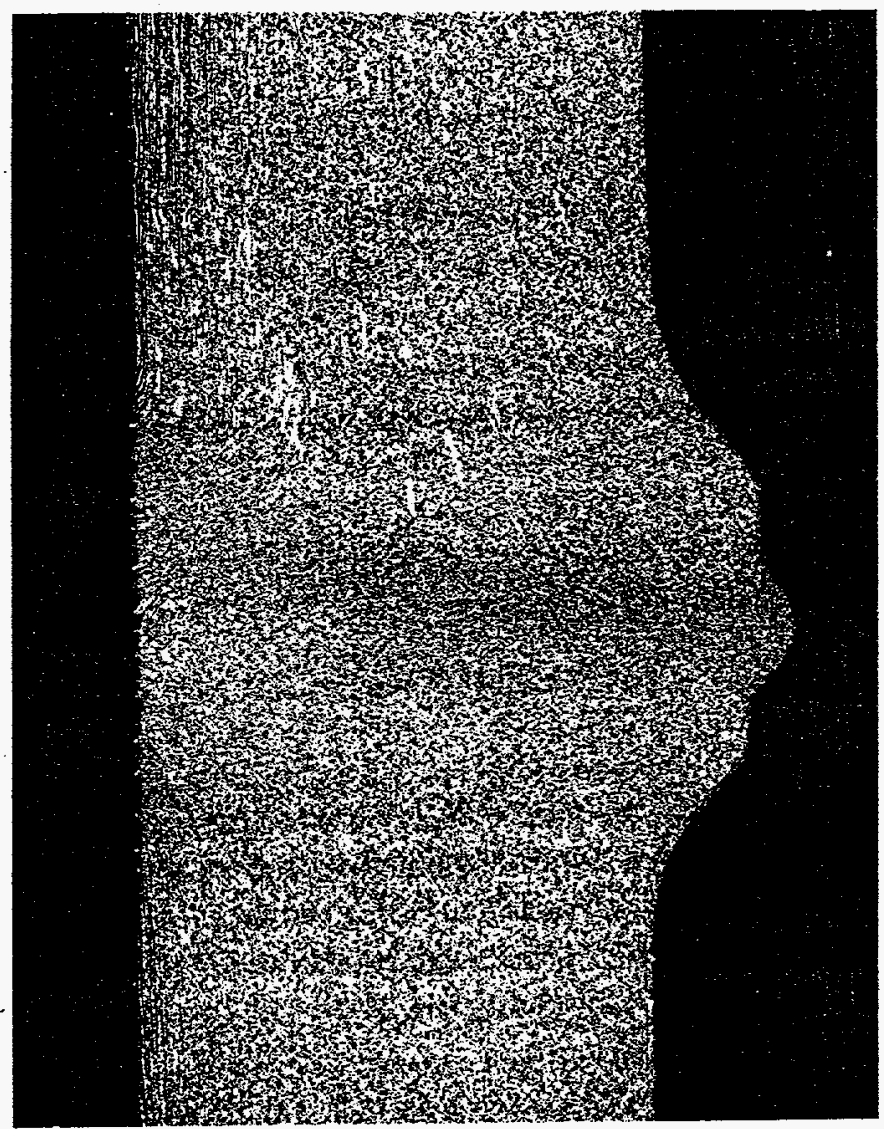

Figure 6. Metallographic section of solid-state resistance weld joining two pipe sections 2.5 inches diameter with 0.2 inch wall thickness demonstrating fabrication capability for large parts. Outside surface of pipe, left, has been machined smooth. Inside surface, right, shows weld upset configuration generated during welding. 